\title{
ОЛЬФАКТОРНЫЕ КОМПОНЕНТЫ ТЕХНОЛОГИИ ПИТАНИЯ КОРЕННЫХ НАРОДОВ ДАЛЬНЕГО ВОСТОКА
}

\section{С.В. Березницкий}

В статье рассматриваются основные аспекты традиционной пищевой культуры, технологии питания коренных народов Дальнего Востока России с учётом такого важного компонента, как запах. Особенности влияния ольфакторных компонентов выявляются не только в хозяйственно-культурном типе северных этносов, но и в комплексе их мифологических воззрений, верований, ритуалов жизненного цикла, шаманстве.

Ключевые слова: коренные народы Дальнего Востока России, традиционная и современная технология питания, специфический способ культурного самовыражения, запахи и обоняние.

\section{OLFACTOR COMPONENTS OF NUTRITION TECHNOLOGY OF THE RUSSIAN FAR EAST INDIGENOUS PEOPLES}

\section{S.V. Bereznitsky}

The article deals with the main aspects of traditional food culture and nutrition technology of the indigenous peoples of the Russian Far East, taking into account such an important component as smell. Features of influence of olfactory components are revealed not only in economic and cultural type of northern ethnoses, but also in a complex of their mythological views, beliefs, life cycle rituals, and shamanism.

Key words: indigenous peoples of the Russian Far East, traditional and modern nutrition technology, a specific way of cultural expression, smells and olfaction.

Этническая кухня является сложной системой коллективных представлений о пищевых привычках и предпочтениях народа, наибольшее значение в которой имеют репрезентативные блюда, позволяющие потребляющему их человеку считать себя органической частью родной культуры. Кроме своей утилитарной функции, пища имеет важное символическое значение, выступая знаком, символом, текстом, который требует интерпретации [39: с. 7]. Среди этой знаковой составляющей большую роль играет запах. Проблематикой запахов как особым дискурсом культуры занимаются представители многих дисциплин: этнографии, антропологии, культурологии, социологии, биологии, психоаналитики, литературоведения, лингвистики [1: с. 10-11]. Запах, с одной стороны, связывает человека природой, а с другой - маркирует культурную границу и подчеркивает его социальность.

Э. Синотт выделил три основных вида запахов: естественные, искусственные и символические (ольфакторные метафоры). Причем значения запахов конструируются индивидуально и социально, так как сами по себе запахи не имеют значения и только люди решают, какие они в данной ситуации [42: p. 158-161; 44].

Проблема изучения функционирования запаха, ольфакторных компонентов в культуре предстает как один из актуальных аспектов, поскольку в современном мире наблюдается тенденция увеличения роли искусственных запахов в системе жизнедеятельности человека, создаётся искусственная обонятельная среда. Исследование социокультурного института запаха начинается еще античными мыслителями (Аристотель, Демокрит, Эпикур), первые концепции, посвященные проблеме обоняния, появились только в XVIII-XIX вв. (Ф. Рюйш, Л. Якобсон, Ф. Вик д’Азир). В ХХ в. были созданы теории обонятельной системы Р. Монкриффа, Д. Эймура, Л. Тьюрина. В настоящее время наиболее известна ольфакторная концепция Л. Бака и Р. Акселя. Считается, что им удалось открыть для человечества дверь в совершенно не исследованную область обоняния. Они выяснили, что существуют около тысячи генов, каждый из которых связан с обонятельным рецептором. Бак и Аксель разгадали механизм того, как люди могут запоми-

Березницкий Сергей Васильевич - доктор исторических наук, профессор, заведующий отделом этнографии Сибири Музея антропологии и этнографии имени Петра Великого (Кунсткамера) РАН (г. Санкт-Петербург).

Bereznitsky Sergei Vasilievich - Doctor of Historical Sciences, Professor, Leading researcher of the Department of Ethnography of Siberia at Peter the Great Museum of Anthropology and Ethnography (the Kunstkamera), Russian Academy of Sciences (Saint-Petersburg).

E-mail: svbereznitsky@yandex.ru 
нать и представлять в своем воображении различные запахи даже в тот момент, когда этих запахов нет в действительности [40: р. 175-187; 23: с. 3-5].

Запах как компонент культуры обладает этносоциальным значением, поскольку является неотьемлемой частью индивидуальной и общественной жизни, играет важную роль в системе коммуникации. Всем живым существам свойственна хеморецепция - сложный механизм восприятия химических сигналов, знаков, стимулов из окружающей среды - для выполнения важнейших жизненных потребностей: трофических (модель питания), репродуктивных (размножение), социальных. Особую роль ольфакторные компоненты играют в процессе обмена информацией как специфического способа невербального общения, передачи культурных ценностей. С архаического этапа человеческой культуры запахи используются в различных сферах жизнедеятельности человека: в мифологии, верованиях, медицине, кулинарии, парфюмерии, гендерных отношениях. Запах оказывает мощное влияние на мироощущение, предупреждает об опасности, воздействует на самочувствие человека, возбуждает или успокаивает, угнетает или вызывает положительные эмоции и приятные воспоминания. В настоящее время западный человек всё больше существует в искусственно созданном миpe, который всё меньше нуждается в использовании обоняния в полной мере, а обонятельный аппарат утрачивает свою первоначальную роль в социокультурной адаптации [35: с. 2-7; 36]. Однако это правило не распространяется на этносы, система жизнедеятельности которых и сегодня основана на хозяйственно-культурном типе охотников, собирателей и рыболовов.

Знаковый эффект аромата считается одновременно самым мощным и самым хрупким компонентом культуры и эпохи. Запахи связаны с телом человека, с его интуицией, памятью и воображением. Запах - это пограничный слой между телом, вещью и внешней средой [1: с. 5-6]. Вопрос об оценочном восприятии запахов зависит от этнокультурных особенностей общества и человека, от традиций, специфики системы воспитания, этнических отличий обонятельных впечатлений, от кулинарных традиций и гигиенических установок народа, от степени терпимости по отношению к инокультурным проявлениям. Чрезвычайно широк разброс оценок запахов и ароматов, считающихся приятными, а также неприятными (запахи кала, мочи, гниющих продуктов) [1: с. 10-11].

Неприятные запахи, сопровождающие специфические блюда, широко известные в традиционной и современной культуре европейских и азиатских народов, нередко расцениваются вполне позитивно. Достаточно привести примеры знаменитых во
Франции, Великобритании, Германии, Бельгии, Австрии, Нидерландах, обладающих нежным, сливочным вкусом, но «вонючих» сортов сыра «Рокфор», «Вонючий епископ», «Лимбургер», которые пользуются огромной популярностью у гурманов, несмотря на большую стоимость этих продуктов. У приморских европейцев (Швеция, Норвегия, Исландия) широко распространенными являются блюда, изготовленные из ферментированной, протухшей рыбы, с соответствующим очень резким, неприятным запахом. Например, знаменитая шведская селедка сюрстрёмминг. Процесс её ферментации занимает около полугода в результате жизнедеятельности анаэробных галофильных микроорганизмов, изначально содержащихся в сельди. Эти микроорганизмы синтезируют диоксид углерода, пропионовую, уксусную кислоты и сероводород, который и является источником специфического запаха. В эту же категорию особо «ароматных» блюд следует отнести норвежскую форель ракфиск и треску лютефикс, исландское блюдо хакарл из приготовленного с помощью такой специфической технологии мяса полярной акулы. Байкальский регион всемирно известен своим фирменным блюдом - омулем «с душком» [33: с. 23-29; 42: p. 18-24]. В пищевой модели корейцев имеется блюдо хонгео из мяса ската, которое длительное время приготавливается под землей. Специфическими блюдами китайцев является «вонючий» соевый сыр тофу, который смешивают с овощами, травами, креветками и оставляют на несколько недель ферментироваться. Все иностранные туристы, побывавшие в Китае, с помощью своих китайских друзей или коллег познакомились с «тухлыми» утиными яйцами, которые покрываются особой смесью травяных настоев, извести, соли, золы и закапываются на несколько месяцев в землю. Многие, но не все японцы с удовольствием завтракают прокисшими бобами натто. Это блюдо часто используется в ресторанах при совместных трапезах с иностранными учеными или бизнесменами, прибывшими по своим делам в Японию. После официальной части наступает время «побратимства», когда японцы-хозяева угощают всю компанию за свой счет своими любимыми блюдами, а натто выступает маркером патриотизма для японцев и показателем бесстрашия и лихости у иностранцев.

Многое зависит от концентрации запаха: даже приятный аромат, если он становится слишком сильным и резким, начнет раздражать обоняние человека, как и самый смрадный запах. Амбивалентность ситуации заключается в том, что обоняние человека физиологично, а символизация запаха зависит от этнокультурных установок: обонятельное, ольфакторное впечатление является феноменом сознания, вызванным действием определенных веществ [1: с. 8-9]. Британский антрополог Мэри 
Дуглас подчеркивает необходимость учёта ситуативного и пространственного факторов, в частности, по её мнению, грязь - это «беспорядок», это смещение границ привычного, это вещь не на своём месте [22: с. 23].

Коренные народы Севера, Сибири, Дальнего Востока, Северной Америки очень широко применяют в традиционной и современной пищевой модели блюда из ферментированной рыбы и мяса сухопутных и морских животных [14: с. 26; 34: с. 372]. Еще русские первопроходцы XVII-XVIII вв. были поражены специфическим запахом «кислой» рыбы, другими этнокультурными особенностями хозяйства, быта, жизнеобеспечения аборигенов Сибири и Севера, с которыми они познакомились во время первых контактов [32].

Наиболее известным, даже для людей, никогда не занимавшихся этнографией коренных народов Севера, является чукотское блюдо копальхен. Это специально подготовленный в диете олень, которого убивали и закапывали в земляных ямах в тундре и оставляли там на несколько месяцев. В результате ферментации мяса и жира сохранялись витамины, микроэлементы и прочие полезные вещества, которых в суровой арктической природе получить было негде. По наблюдению очевидцев, куски этого блюда чукчи с удовольствием глотали, не пережёвывая [8: с. 65-66; 17: с. 539-541]. Известность это блюдо получило именно из-за очень своеобразного, резкого, специфического запаха ферментированного мяса. Употреблявшие его европейские исследователи, путешественники свидетельствуют, что в замороженном виде запах можно вытерпеть. Огромной популярностью пользуются китовые почки, оленья печень «с душком». Вообще в традиционной культуре чукчей считалось грехом не употреблять в пищу павших сухопутных животных или выброшенных штормами на берег и полуразложившихся морских животных [14: с. 127-128; 38: с. 177]. В.Г. Богораз подчеркивал ольфакторную избирательность чукчей, которые с удовольствием ели ферментированные с очень сильным специфическим, гнилостным запахом продукты, но не могли вытерпеть запаха медикаментов из дорожного саквояжа исследователя, чужеземного запаха консервов, продуктов, даже сахара [15: с. 21]. Культурное содержание символики запахов детерминировано этнокультурным контекстом и оказывает специфическое воздействие на человека. Например, те же чукчи могут описывать с помощью запаха различные предметы. Вещи из западной культуры, даже самые безобидные с позиции европейского менталитета, у чукчей вызывают настолько сильные ольфакторные реакции, что некоторые из них падают в обморок. Непонятность, необычность того или иного европейского предмета была связана в представлении чук- чей, прежде всего, с его дурным запахом, незнакомые вещи обладали зловонным смрадом, что нередко приводило некоторых из них к истерии или к психическому расстройству [35: с. 2-7].

Проживавший постоянно в конце 1990-х гг. на одном из морских заливов в окрестностях с. Венское, в заливе Ногликского района Сахалинской области, нивхский рыбак извлекал необходимые для организма витамины из рыбьего жира, который самостоятельно вытапливал. Однажды он угостил этим жиром японского корреспондента, задохнувшегося на время запахом рыбы, хотя японцы известны как древние ихтиофаги. Рыбак критически относился к молодёжи, которая стремительно переезжала в города, забывая родную культуру: «Те, кто в город уехали, нивхскую жизнь позабывали. Сейчас уже от запаха рыбы нос воротят. Что за люди?». Кстати и название п. Ноглики на нивхском языке означает «вода, пахнущая жиром». В заливе уже давно обнаружены богатейшие залежи нефти и газа [24]. В 2019 г. ногликский нивх Г.Н. Псягин также с горечью говорил о том, что главная причина отсутствия среди нивхов охотников связана с тем, что у людей нет желания употреблять в пищу мясо и сало нерпы, нивхи не только потеряли мастерство этой древней охотничьей технологии, но многих уже отталкивает запах нерпичьего мяса. Однажды сотрудник краеведческого музея в Южно-Сахалинске попросил Г.Н. Псягина прислать ему мясо и жир нерпы в качестве природного, проверенного народной медициной лекарства. Информант купил необходимые продукты, собрал посылку, но отправить её из Ноглик в Южно-Сахалинск не смог, потому что ни один пассажир в поезде не согласился везти мясо и сало нерпы из-за специфического запаха [37].

Специалисты в сфере современных пищевых технологий чукчей подчеркивают вкусовые отличия рыбы, приготовленной в тундре и в посёлке. В первом случае качество рыбы выше, так как она пропитывается запахом тундры, яранги, дыма от костра. И, самое главное, это блюдо не требует добавления соли, как в варианте домашнего приготовления [21: с. 149]. Хорские удэгейцы вспоминали, как в традиционной культуре при приготовлении впрок особого блюда косу из вяленого и немного копченого на костре мяса изюбря нужно было тщательно выбирать породу дерева для дров. В первую очередь старались использовать ясень, так как изготовленные из него дрова не только ярко горят, дают хорошие крупные угли, но и мясо получается очень вкусное и совершенно не пахнет дымом. Хвойные породы для этой цели не годятся, так как мясо вбирает в себя смолистый запах и становится неприятным на вкус [10: с. 121, 320]. 
Многолетний этнологический мониторинг в Ненецком автономном округе показал, что, несмотря на современные экологические проблемы, фундаментальные противоречия с нефте- и газодобывающими компаниями, ненцы занимаются традиционными видами промыслов: оленеводством, охотой, рыболовством, сбором дикоросов. При этом объем потребляемого оленьего мяса в год на одного человека в среднем составляет 50-250 кг, рыбы 60-300 кг [31: с. 4]. Цифры наглядно показывают кардинальное отличие структуры питания тундровиков от городских жителей. На примере исследования современной технологии питания коренных народов Северо-Восточной Азии ученые приходят к справедливому выводу о том, что человек волен самостоятельно выбирать между традиционным и современным способом приготовления, заготовки впрок и потребления продуктов. Вкусовые, обонятельные, тактильные, сенсорные пищевые восприятия в огромной степени связаны с этнокультурной и социокультурной рефлексией прошлого образа жизни в тундре, с воспоминаниями о детстве и предках. Технологии использования коренными народами Севера в пищу не обработанных на огне, но применяемых для длительного хранения продуктов из крови животных, мяса и рыбы, «заквашенных» в специально приготовленных емкостях или ямах с использованием в качестве консервантов и ароматизаторов растительного сырья, необходимы для обогащения организма витаминами за счет их синтеза микрофлорой кишечника. Многие традиционные чукотские блюда бытуют и в настоящее время с несколько изменённой технологией приготовления: в частности, продукты стали чаще замораживать, чем ферментировать. Однако сохраняется мощный этнокультурный механизм противопоставления своей сытной чукотской пищи и русской, после которой человек часто остаётся голодным. Современные чукчи при употреблении в пищу ферментированного мяса сухопутных и морских животных стараются дистанцироваться от своих соседей из инокультурной среды [28: с. 265, 269, 271-272, 274-280, 292-293, 303-305 и др.; 30: с. 108-111, 121-122, 133, 138, 149 и др.; 19: c. $128-147 ; 21$ : c. $150 ; 20$ : c. $43-60 ; 16$ : с. $119-126$; 41: p. 27-34; 25: c. 60, 64-65]. Однако в основе этого дистанцирования лежит не стеснительность, а осмысленное разграничение этнокультурных миров, желание насладиться любимым блюдом в окружении единомышленников. Селемджинские эвенки отчетливо помнят начало трансформации их традиционной пищевой модели в 1950-60-х гг., связанной с «насильственным» насаждением властями непривычной хозяйственной отрасли - свиноводства при создании постоянных поселков для привития оленеводам осёдлости. Ольфакторный компонент проявился, прежде всего, в неприятии эвенками «ужасного» для них запаха свиного навоза, который стал постепенно, но уверенно компенсироваться «великолепным» запахом жареного свиного мяса, сала, приготовляемых колбас и других блюд из свинины. Однако самые первые «любители» этого мяса скрывали свое пристрастие от сородичей, более склонных к сохранению пищевых традиций [9: с. 243].

Как подчеркивал в своё время знаменитый К. Леви-Стросс, в таких ситуациях люди выходят за пределы оппозиции чувственно воспринимаемого и понимаемого, сразу переходя на уровень знаков. При этом логические свойства проявляются как атрибуты вещей, доступных непосредственному восприятию, таким показателям, как вкус и запах. Специфика последних рождает особую комбинацию элементов для восприятия запаха. Для получения ситуации комфортного режима поглощения пищи необходима умеренная несдержанность и открытость: звуки пережевывания пищи, ее специфический запах, а также способность абстрагироваться и перевести неприятные элементы быта в приятные. Разрабатывая бинарную оппозицию «сырое/гнилоеприготовленное», Стросс выявил, что мифология даёт очень образные примеры того, как люди осознают соотношение смерти с гниющим мясом, обладающим смрадным запахом. Однако часто ошибка заключалась в неполноценности обонятельной чувствительности людей, неумении их не замечать этого запаха, как это делают змеи, камни, деревья, обладающие бессмертием [29: с. 22, 133, 162-165, 176].

Таким образом, ольфакторные компоненты занимают определённое место не только в быту, в пищевой модели, но также и в мифологии, верованиях и ритуалах народов мира. В том числе и в комплексе соответствующих воззрений и практик коренных народов Дальнего Востока, например в удэгейском предании о злом духе-людоеде, нападающем на людей в виде огромной железной птицы, которая живет на огромном железном дереве, стоящем на высокой железной горе. Под этой железной горой есть еще одна гора человеческих костей и черепов. Находит людей эта птица по их специфическому запаху [12: с. 163-164].

Ольфакторные компоненты присутствуют в ритуалах жизненного цикла в целях защиты новорожденных от злых духов-людоедов. Известно, что детская смертность в традиционной культуре коренных народов Дальнего Востока была чрезвычайно высока, так как была связана с этнокультурными особенностями рождения ребенка и ухода за ним. В соответствии с мифологическими представлениями факт рождения ребенка и появления его на свет, в земном мире, был очень опасным моментом не только для роженицы, её мужа, ближайших род- 
ственников, но и всех сородичей. Возникновение новой жизни привлекало злых, вредоносных и болезненосных сверхъестественных существ. Именно поэтому роженица удалялась из социальной группы в отдельное временное жилище и должна была сама родить ребёнка, не привлекая злых духов криками боли. По этой же причине она сама поддерживала огонь в очаге в зимнее время. Сама приносила воду и всё необходимое для себя и ребенка. В случае осложненных родов общество могло пойти ей навстречу и послать на помощь пожилую женщину, имевшую много детей и соответствующий опыт. Однако это было чревато будущими насмешками, как, например, в культуре чукчей [15: с. 20]. В самых тяжелых обстоятельствах могли пригласить шамана, если была такая возможность (шаман жил неподалёку и не был занят другими делами). Если новорожденные часто умирали у конкретной роженицы, то для сохранения жизни очередного применяли магические ритуалы, мальчикам давали женские имена, а девочкам мужские, чтобы запутать духов. Часто давали новорожденным неблагозвучные имена, связанные с названием половых органов, ануса, экскрементов. В последних случаях надеялись на то, что ассоциированный с этими названиями неприятный запах оттолкнёт злых существ и ребенок останется жив. Если же становилось известно, что за новорожденным охотятся наиболее опасные злые духи-людоеды, то тогда прибегали к очень необычному, но действенному, по уверению информантов, приёму: младенца некоторое время «коптили» в дыму горящего собачьего кала. Потенциально приближающийся духлюдоед убегал от страшного смрада, что спасало ребёнку жизнь. У сахалинских нивхов в 1998 г. было записано предание о том, как особые таежные люди-великаны ге нивгуны похитили и в своей пещере коптили в дыму от горящего собачьего кала одного нивха, который употреблял в пищу очень много собак. Сородичи расценили этот случай как предупреждение высших сил о недопустимости чрезмерного гастрономического пристрастия этого человека [13: с. 327-329].

Сбивали аппетит духов-людоедов и тем, что новорожденного засыпали мусором [18: с. 55]. Учитывая большую роль в пищевой модели рыбы, мяса морских и таёжных зверей, можно предположить, что этот мусор также издавал неприятный запах. По крайней мере, великий И. Кант писал по этому поводу, что грязь возбуждает отвращение не столько визуально, сколько по причине того, что от неё ожидают дурного запаха, а вдыхание запаха имеет даже большее значение, чем поглощение пищи [27: с. 390-391].

Важную роль запах имел в промысловых ритуалах. Так, удэгейские рыбаки перед началом рыбной ловли совершали ритуал жертвоприношения в честь хозяина воды: на речной косе они строили жертвенник, в песок втыкали палку, сверху клали плоский камень и на нем на углях жарили нос, боковые плавники и хвост рыбы [5: с. 243]. Жертва поступала к хозяину водной стихии вместе с дымом и запахом. По представлениям корейцев, душа покойного вкушала запахи от еды и благовоний, поднимающихся вверх [26: с. 85-88]. При добыче соболя капканами самыми лучшими приманками считались тухлая рыба, протухшая дикая птица. По мнению охотников, соболь обожает эти неприятные для человека запахи. Во время проведения в традиционной культуре медвежьих праздников (после добычи зверя на охоте) нивхи приманивали медведя тухлой рыбой, запах которой он обожает. Затем священного зверя убивали и проводили ритуал [13: с. 149-151]. Очень интересным представляется мнение коренных народов амуро-сахалинского региона о том, что мясо у «домашнего» медведя (т.е. медведя, которого еще медвежонком помещали в сруб и в течение 2-3 лет выращивали для предстоящего медвежьего праздника) лучше, чем у дикого, нежнее и не пахнет рыбой.

По мнению амгуньских негидальцев, чрезвычайно чуткий нюх собаки помогает ей защититься от каннибализма. Так, однажды охотники принесли домой енотовидную собаку для того, чтобы кормить ее мясом и жиром домашних собак. Но, только понюхав это блюдо, домашние животные отказались его есть [11: с. 452].

Выявляются особенности, связанные с пищевыми запретами: удэгейцы не употребляли в пищу мясо косатки из-за того, что считали её священным предком, морским человеком, а мясо кита - из-за его специфического запаха. Косатка может ходить по суше, используя змею в качестве посоха, белое брюхо косатки испускает свет, это морское китообразное может кричать как человек и помогает людям в промысле нерпы [2: с. 783, 857; 4: с. 22; 5: с. $244 ; 6$ : с. $125 ; 7$ : с. 206]. У современных негидальцев сохранились воспоминания о том, как некоторые их предки долго не могли привыкнуть употреблять в пищу картофель, из-за того что для них этот овощ сильно пах землей [11: с. 495].

Ольфакторные компоненты выявлены и в таком важном культурном институте коренных народов Дальнего Востока, как шаманство. Для вхождения шамана в транс применялись различные вещества, в том числе наркотические (в основном болотный багульник). Удэгейцы и орочи собирали багульник заранее и сушили, а во время камлания воскуривали на огне. Считалось, что шаманским духам очень нравится запах багульника и его дым. Перед началом камлания одетого в костюм шамана обтирали дымящимися листьями багульника, шаман пил 
настой багульника и настой багульника с золой или сажей, но был убежден в том, что пьет настой не он, а его духи-покровители, которым очень нравился запах и вкус этого напитка. Этим же обстоятельством шаман объяснял присутствующим на сеансе его возможность выпивать большой объём спиртных напитков. Дымящимися листьями багульника натирали тело больного при камлании и давали дышать парами настоя; употребляли клубни специальных трав [3: с. 203; 5: с. 245; 6: с. 77]. В предании сахалинских нивхов, ульта говорится о том, как пожилые охотники на нерпу спаслись от злого духа в виде обольстительной женщины, погубившей их молодых сородичей. Впоследствии они стали шаманами и тут же приказали своим жёнам выбросить из жилищ лук, так как шаманы не выносят его запаха.

Таким образом, в пищевой культуре многих народов мира присутствуют блюда, обладающие резким, отвратительным запахом. Причем запах этот появляется именно после особой технологии приготовления обычных продуктов, результатов охоты, скотоводства, рыбной ловли. Если синтезировать несколько основных версий о причинах приготовления указанных выше продуктов, то все они объединяются отсутствием в традиционной культуре или дороговизной соли, отсутствием холодильных установок, вакуумных упаковок, необходимостью брать с собой в длительные путешествия запас белковой пищи с условием того, чтобы он не испортился. Самое ценное заключается в том, что в настоящее время соль не является дефицитом, а путешествовать можно с комфортом по всему миру, не делая дорожных пищевых запасов. Следовательно, современная технология основана на традиции прежних пищевых моделей, в которой огромную роль играет именно специфический запах. Люди едят эту рыбу или перечисленные выше сыры и другие блюда, чтобы еще раз прикоснуться к своей истории, проверить на себе любовь к родной культуре.

Мифология, фольклор, комплекс верований и ритуалов, народная педагогика, технология питания в целом коренных народов Дальнего Востока пронизаны и насыщены сюжетами об использовании в традиционной и современной пищевой культуре продуктов, блюд, обладающих специфическим запахом. Сохранение этого механизма большей частью современных аборигенов, которым доступны практически все виды европейской кухни, ярко свидетельствует о том, что главной причиной является следование традициям своего народа, сохранение своей идентичности, этнического самосознания, уважение родной истории. Описанные выше пищевые, вкусовые и ольфакторные предпочтения помогают коренным народам сохранять привычный хозяйственно-культурный тип, самобытные промыслы, окружающие природные ландшафты. Ольфакторные компоненты пищевой модели многих этнических общностей, расселенных в разных климатических зонах, сходны с подобными показателями коренных народов Дальнего Востока, что подтверждает их архаичность, стойкость в процессе межпоколенной трансляции и позволяет отнести в разряд не только специфических этнокультурных ценностей, но и в целом, к общемировому культурному наследию.

\section{ЛИТЕРАТУРА}

1. Ароматы и запахи в культуре. Кн. 1 / сост. О.Б. Ванштейн. - Изд. 2-е. - Москва : Новое литературное обозрение, 2010. - 616 c.

2. Арсеньев, В.К. Путевой дневник 1908-1909 гг. / В.К. Арсеньев // Архив ПЦРГО-ОИАК. - Ф. В.К. Арсеньева. - Оп. 1. - Д. 4. - С. 783, 857.

3. Арсеньев, В.К. Путевой дневник 1. 1908-1909 гг. / В.К. Арсеньев // Архив ПЦРГО-ОИАК. - Ф. В.К. Арсеньева. - Оп. 1. - Д. 10. - С. 203.

4. Арсеньев, В.К. Путевой дневник 2. Юбилейная экспедиция 1908-1909 гг. в память присоединения Приамурского края к России в 1860 г. / В.К. Арсеньев // Архив ПЦРГООИАК. - Ф. В.К. Арсеньева. - Оп. 1. - Д. 11. - С. 22.

5. Арсеньев, В.К. Путевой дневник 1. 1914-1925 гг. / В.К. Арсеньев // Архив ПЦРГО-ОИАК. - Ф. В.К. Арсеньева. - Оп. 1. - Д. 27. - С. 243-245.

6. Арсеньев, В.К. Путевой дневник 2. 1914, 1917, 1926, 1927 гг. / В.К. Арсеньев // Архив ПЦРГО-ОИАК. Ф. В.К. Арсеньева. - Оп. 1. - Д. 28. - С. 77, 125.

7. Арсеньев, В.К. Собрание сочинений. В 6 т. Т. $5 /$ В.К. Арсеньев. - Владивосток : Примиздат, 1948. - 221 с.

8. Афанасьева, Г.М. Традиционная пища береговых и оленных чукчей / Г.М. Афанасьева, Ю.Б. Симченко // Народы Сибири. Кн. I: Сибирский этнографический сборник. Москва : Наука, 1993. - Т. 6. - С. 56-100.

9. Березницкий, С.В. Материалы по культуре бикинских и анюйских удэгейцев, селемджинских эвенков. Этнографические исследования 2003-2004 гг. / С.В. Березницкий // Архив ИИАЭНДВ ДВО РАН. - Ф. 1. - Оп. 2. - Д. 559. Владивосток, 2004. - 775 с.

10. Березницкий, С.В. Материалы по культуре бикинских и хорских удэгейцев. Этнографические исследования 2002 г. / С.В. Березницкий // Архив ИИАЭНДВ ДВО РАН. Ф. 1. - Оп. 2. - Д. 522. - Владивосток, 2003. - 401 с.

11. Березницкий, C.В. Материалы по культуре хоккайдских айнов, амгуньских негидальцев и эвенков, горинских нанайцев. Этнографические исследования 2005 г. / С.В. Березницкий // Архив ИИАЭ ДВО РАН. - Ф. 1. - Оп. 2. - Д. 585. - Владивосток, 2006. - 847 с.

12. Березницкий, С.В. Этнокультурные контакты, этническая история и духовная культура коренных народов Нижнего Амура и Сахалина. Этнографические исследования 1997 г. / С.В. Березницкий // Архив ИИАЭНДВ ДВО РАН. - Ф. 1. - Оп. 2. - Д. 415. - Владивосток, 1999. - 182 с.

13. Березницкий, С.В. Этнокультурные контакты, этническая история и духовная культура коренных народов Нижнего Амура и Сахалина. Этнографические исследования 1998 г. / С.В. Березницкий // Архив ИИАЭ ДВО РАН. Ф. 1. - Оп. 2. - Д. 416. - Владивосток, 1999. - 711 с.

14. Богораз, В.Г. Материальная культура чукчей / В.Г. Богораз ; авториз. пер. с англ. ; послесл. и прим. И.С. Вдовина. - Москва : Наука, 1991. - 224 с. 
15. Богораз, В.Г. Чукчи. Ч. 1 / В.Г. Богораз ; авториз. пер. с англ. - Ленинград: Изд-во Ин-та народов Севера, 1934. $-193 \mathrm{c}$.

16. Ватэ, В. Пища, эмоции и социальные отношения у амгуэмских чукчей / В. Ватэ, Е.А. Давыдова // Кунсткамера. - 2018. - № 2. - С. 119-126.

17. Вдовин, И.С. Чукчи. Хозяйство и материальная культура / И.С. Вдовин, Е.П. Батьянова // Народы СевероВостока Сибири / отв. ред. Е.П. Батьянова, В.А. Тураев. Москва : Наука, 2010. - С. 539-541.

18. Гаер, E.А. Традиционная бытовая обрядность нанайцев в конце XIX - начале XX в. / Е.А. Гаер. - Москва : Мысль, 1991. - 128 с.

19. Давыдова, Е.А. «Единственное, в чем я более менее преуспела - в освоении чукотской кухни»: полевая работа В.Г. Кузнецовой в Амгуэмской тундре, 1948-1951 гг. / Е.А. Давыдова // Материалы полевых исследований МАЭ РАН / отв. ред. Е.Г. Федорова. - Санкт-Петербург : МАЭ РАН, 2018. - Вып. 18. - С. 128-147.

20. Давыдова, E.A. Пища как властный ресурс у амгуэмских оленеводов: по материалам В.Г. Кузнецовой / Е.А. Давыдова // Этнографическое обозрение. - 2019б. № 2. - С. 43-60.

21. Давыдова, Е.А. Холодильник, соль и сахар: добыча и технологии обработки пищи на Чукотке / Е.А. Давыдова // Сибирские исторические исследования. - 2019а. - № 2. C. $143-161$.

22. Дуглас, М. Чистота и опасность: анализ представлений об осквернении и табу / М. Дуглас ; пер. с англ. ; вступ. ст., коммент. С.П. Баньковская. - Москва : КАНОН-прессЦ: Кучково поле, 2000. - 286 с.

23. Епанешникова, М.А. Феномен запаха в культуре: особенности функционирования в сакральной и профанной сферах : автореф. дис. ... канд. культурологии : 24.00.01 Теория и история культуры / М.А. Епанешникова. - Екатеринбург, 2011. -24 с.

24. Залив Лена (Леонида Арана). Жизнь вне общества : пер. с япон. // Mainichi Shimbun (Майнити симбун). - 1997. 21 октября.

25. Иванова, Г.В. Особенности питания коренного населения арктической зоны Российской Федерации / Г.В. Иванова, Т.Н. Сафронова // Российская Арктика. - 2018. - № 3. - C. $60-70$.

26. Ионова, Ю.В. Погребальные обряды корейцев / Ю.В. Ионова // Культура народов зарубежной Азии : сб. МАЭ. - Ленинград : АН СССР, 1973. - Т. 29. - С. 80-94.

27. Кант, Иммануил. Антропология с прагматической точки зрения [Anthropologie in pragmatischer Hinsicht] / Иммануил Кант // Сочинения в шести томах. - Москва : Мысль, 1966. - Т. 6. - С. 349-587.

28. Кузнецова, В.Г. Материалы по праздникам и обрядам амгуэмских оленных чукчей / В.Г. Кузнецова // Труды института этнографии им. Н.Н. Миклухо-Маклая. Новая серия. - 1957. - Т. XXXV. - С. 263-326.

29. Леви-Стросс, Клод. Мифологики. В 4 т. Т. 1. Сырое и приготовленное / Клод Леви-Стросс. - Москва ; СанктПетербург : Университетская книга, 1999. - 406 с.
30. Михайлова, E.A. Скитания Варвары Кузнецовой. Чукотская экспедиция Варвары Григорьевны Кузнецовой. 1948-1951 гг. / Е.А. Михайлова ; отв. ред. Л.Р. Павлинская. - Санкт-Петербург : МАЭ РАН, 2015. - 190 с.

31. Мурашко, O.А. Трансформации традиционного образа жизни и питания коренного населения ненецкого автономного округа / О.А. Мурашко, В.К. Даллманн // Вестник Московского университета. - 2011. - № 4. - С. 4-24. (Серия XXIII. Антропология).

32. Народы Сибири в составе государства Российского (очерки этнической истории) / отв. ред. Л.Р. Павлинская. Санкт-Петербург : МАЭ РАН. 1999. - 359 с.

33. Никифорова, А.П. Применение ферментации для переработки рыбы и морепродуктов: обзор / А.П. Никифорова // Байкальский вестник DAAD. - 2018. - № 1. - C. 23-29.

34. Основы морского зверобойного промысла : научнометодическое пособие / Л.С. Богословская [и др.] ; науч. ред. Л.С. Богословская. - Москва; Анадырь : Институт Наследия, 2007. - 479 с

35. Папченко, E.B. Роль невербальной коммуникации в культуре / Е.В. Папченко // Гуманитарные и социальные науки. - 2008. - № 5. - С. 2-7.

36. Папченко, E.B. Социопсихические и культурные функции запаха в жизнедеятельности человека : автореф. дис. канд. филос. наук : 09.00.13 / Е.В. Папченко ; Рост. гос. ун-т. - Ростов-на-Дону, 2003. -25 с.

37. ПМА-2019: полевые материалы автора - этнографические исследования С.В. Березницкого на Сахалине в 2019 г.

38. Теин, Т.С. Науканские эскимосы и чукчи Уэлена: использование продукции китобойного промысла / Т.С. Теин, В.В. Леонтьев, Л.С. Богословская // Тропою Богораза; научные и литературные материалы / сост. и науч. ред. Л.С. Богословская, В.С. Кривощеков. И.И. Крупник. Москва, 2008. - С. 177-178.

39. Anderson, E.N. Everyone Eats: Understanding Food and Culture / E.N. Anderson. - New York : New York University Press, 2005. -294 p.

40. Buck, $L$. A novel multigene family may encode odorant receptors: A molecular basis for odor recognition / L. Buck, R. Axel. - 1991. - Cell 65. - P. 175-187.

41. Davydova, E.A. Diet of the north-eastern Chukotka reindeer herders: the change of food autonomy regime / E.A. Davydova, V.N. Davydov // 5th International Multi-disciplinary Scientific Conference on Social Sciences and Arts SGEM 2018. Conference Proceedings, Vol. 5. Ancience Science, Issue 2.2. Anthropology, Archaeology, History, Philosophy, Medieval and Renaissance Studies. - Sofia: STEF92 Technology Ltd. P. 27-34.

42. Martynova, E.V. Anomalies of olfactory bahaviour / E.V. Martynova // Scientific notes of Orel State University. 2015. - Vol. 6, № 69. - P. 158-161.

43. Fermented and ripened fish products in the northern European countries / T. Skara, L. Axelsson, G. Stefansson, B. Ekstrand, H. Hagen // Journal of Ethnic Foods. - 2015. № 2. - P. 18-24.

44. Synott, A. The body social: symbolism, self, and society / A. Synott. - London : New York : Routledge, 1993. - 320 p. 